\title{
China's Tributary System and National Security in the Song Dynasty
}

\author{
Huang Chunyan 黃純灎 \\ Professor of History, Yunnan University, China \\ chunyanhuang@sina.com
}

\begin{abstract}
China's ancient tributary system not only served the vanity of the dynasty but had multiple political implications, closely tied to the dynasty's national security. The Song dynasty's [960-1279] notion of security followed an overall policy of guarding the dynasty against external threats, surrounding barbarian nations, and maintaining domestic order. The stability and eventual collapse of the tributary system were closely tied to the domestic security of the Song dynasty and to the security of all the countries that participated in the system. The system constituted a dynamic and interactive security community.
\end{abstract}

\section{Keywords}

national security - Song dynasty - tributary system

China's ancient tributary system was developed from the perspective of China's centralized dynastic rule, in which the dynasty played the key role in defining the basic distinction between Chinese and barbarian, in which tribute constituted a vertical protocol for international relations in fundamental relationships. The tributary system was built not merely to satisfy the vanity of the central country and to benefit the smaller country but also had practical applications. The tributary system was an international protocol closely tied to the national security of the Song dynasty [96o-1279] and influenced the security of all the countries that participated in the system. This article discusses how the operation of the Song dynasty's tributary system and its existence and 
discontinuation affected the security of relations between the Song dynasty and the various political entities in the tributary system.

\section{The Concept of National Security in Ancient China and in the Song Dynasty}

\subsection{Early China's Concept of National Security}

To understand the particular characteristics of ancient China's concept of national security, the concept of the "nation-state" in ancient China must first be clarified. The concept of the nation-state in ancient China is based on the concept of a "realm" [tianxia 天下]. A realm is described as a geographic space consisting of the nine administrative regions and the four seas, referred to in the "Chapter on the Imperial System [Wangzhi 王制]" in the Book of Rites [Liji 禮記] as "the nine administrative regions encompassed by the four seas."1 This is what we refer to as the "nine administrative regions-four seas" construct of a realm. The "four seas" is a natural geographic concept, based on the four seas to the north, south, east, and west, which constitute the natural borders of the realm. At the same time, the four seas is a concept that includes a geographical concept of political geography. The "Chapter on Geography [Shidi 釋地]" in Erya 爾雅 states:

The nine barbarian groups to the east, the eight barbarian groups to the north, the seven barbarian groups to the west, and the six barbarian groups to the south are called the four seas. ${ }^{2}$

These four "barbarian groups" [siyi 四夷] surrounding China on four sides are what the "four seas" refers to in political geography. Accordingly, the concept of a realm as "nine administrative regions - four seas" also refers to the ethnic groups of the Chinese people and the surrounding barbarians. This "Chinafour barbarian groups" construct became the conceptual foundation for building national security throughout successive dynasties.

The most basic tenet of the concept of national security in ancient China was the overall security of the Chinese nation and the barbarian peoples who surrounded it. China's ancient dynasties believed that establishing a protocol under which Chinese authority pacified the four barbarian groups was the greatest guarantee and ideal model of national security. The Zuo Commentary

1 Wang Yunwu 王雲五 and Zhu Jingnong 朱經農, ed., “Wangzhi 王制 [Imperial System],” in Liji 禮記 [Book of Rites] (Shanghai: Shangwu yinshu guan, 1947), 3.

2 Guo Pu 郭璞, “Shidi 釋地 [Geography]," in Erya 爾雅 (Beijing: Zhonghua shuju, 1985), 84. 
[Zuozhuan 左傳] states: "In ancient times, the Son of Heaven (the emperor) held the four barbarian groups in check." ${ }^{3}$ In other words, in the emperor's eyes, national security could most ideally be guaranteed through the voluntary submission of the four barbarian groups to the Chinese court. Accordingly, national security entailed the overall stability of the barbarian groups.

National security was further founded on maintaining domestic order and securing the nation against external threats, in the belief that the key to pacifying the four barbarian groups was the "middle kingdom" [中國], which enjoyed peace and social order. The concept of Chinese versus barbarian emphasized the importance of China and diminished the status of the barbarian groups. The "middle kingdom," which is the literal translation of "China," was the core of Sino-barbarian relations. Li Daliang 李大亮 [586-644] of the Tang dynasty [618-907] once said, "The people of China constitute the root, while the people of the four barbarian groups are like the branches and leaves." Emperor Taizong 唐太宗 [r. 627-649] of the Tang dynasty said that the best policy for controlling the four barbarian groups was "to maintain order and peace in China, with the result that the barbarian groups would naturally submit to Chinese authority." ${ }^{5}$ Such statements emphasize that governing the middle kingdom well, "maintaining internal order and stability while guarding against external threats," was the best course of action. This concept of security was shared by successive dynasties.

Importantly, the concept of national security in ancient China was based on defense. In ancient China it was generally believed that defending was better than mounting an offense in order to guarantee national security and that cultural refinement was more important than military prowess. Confucius once said: "If people from afar do not submit to your authority, attract them with your cultural and ethical attributes." ${ }^{\prime 6}$ The use of culture and ethics was emphasized. Yan You 嚴尤 [d. 23], in his advice to Wang Mang 王莽 [45 BCE-23] on how to handle barbarian relations, said that Xi Zhou [1046-771 BCE], Qin [221-207 BCE], and Han [2O2 BCE-220] did not follow the best policy.

3 “Zhaogong ershisan nian ba yue 昭公二十三年八月 [Eighth Month of the Twenty-Third Year of Zhao Gong's Reign]," in Chunqiu zuozhuan zhushu 春秋左傳注疏 [Commentary and Annotation on the Zuo Commentary], Wenyuange siku quanshu yingyinben 文淵閣四 庫全書影印本 [Photocopy Version of the Wenyuange Edition of the Siku quanshu], ce 144 (Beijing: Zhonghua shuju, 199o), 459.

4 Liu Xu 劉昫, comp. “Li Daliang zhuan 李大亮傳 [Biography of Li Daliang]," in Jiu Tang shu 舊唐書 [Old History of the Tang Dynasty] (Beijing: Zhonghua shuju, 1975), 62.2388.

5 Sima Guang 司馬光, ed., “Tangji 唐紀 [Records of the Tang]," in Zizhi tongjian 資治通鑒 [A Comprehensive Mirror to Aid in Government] (Beijing: Zhonghua shuju, 1956), 193.6067.

6 Huang Kan 皇㑆, Lunyu yishu 論語義疏 [Annotation on the Analects], annot. Gao Shangju 高尚智 (Beijing: Zhonghua shuju, 2013), 423. 
Xi Zhou expelled the barbarians, which was a somewhat effective policy. The Western Han [202 BCE-8] made deep inroads in fighting the barbarians, which depleted the middle kingdom's resources and was therefore a bad policy. The Qin dynasty completely exhausted its resources, which caused the downfall of the dynasty, and had no diplomatic policy with regard to the barbarians. In other words, regardless of the degree to which the state deploys military forces, the result does not constitute the most ideal policy. Emperor Taizong once said the best policy for persuading the four barbarian nations to submit to Chinese authority did not involve the use of force but "involved minimizing military action and promoting cultural discourse. In this way, China would be at peace and the four barbarian groups would voluntarily submit to Chinese authority."

Early China's concept of national security rooted in defense was also closely tied to China's feeling of cultural superiority and agrarian way of life. The economic differences between Chinese and barbarians were to a great extent expressed by the differences between an agrarian economy and a nomadic or fishing and hunting economy. The lands of the four barbarian groups were described as "useless lands" or "lands that could not be cultivated for food crops." Di Renjie 狄仁傑 [630-70o] once said:

The hard, stony ground [inhabited by the four barbarian groups] is not covered with grass and gaining jurisdiction over persons who live there will not increase revenues for the state; if this land is obtained it cannot be farmed or used to cultivate textile crops. ${ }^{8}$

Such land has no economic value. Most of the places where the four barbarian groups live are not suitable for agriculture. "This is how Heaven has restricted the barbarians and divided Chinese from outsiders." 9 The central court's concept of national security took this as the basis of defense against the four barbarian groups.

\subsection{The Song Dynasty's Concept of National Security}

The tributary system and the Song dynasty's national security were defined primarily from the perspective of the dynasty's relations with outsiders. In terms of defense against outsiders, the Song dynasty's primary policy of national security involved a conceptual transformation from "defending against the

7 Sima Guang, "Tangji," 6o85.

8 Liu Xu, “Di Renjie zhuan 狄仁傑傳 [Biography of Di Renjie]," in Jiu Tangshu, 89.2889.

9 Liu Xu, "Di Renjie zhuan," 89.2889. 
four barbarian groups" [shouzai siyi 守在四夷] to “implementing autonomous garrisoning of pre-determined administrative districts and regions and defending them" [huajiang zishou 畫疆自守]. The second feature was preventing war by peaceful means and maintaining domestic order while holding forces outside the realm in check. Prior to the Yongxi 雍熙 campaign [986], the Song dynasty's objective was to establish a unified protocol for the realm in which Chinese-barbarian relations would both remain centered on defeating the Qitans [Qidan 契丹] and developing alliances with various tribes in the northeast and northwest. The Song dynasty envisioned that conditions after the campaign would be as follows:

The insignificant Qitans would be pacified in a short period. Important members of the ruling families of the nations of $\mathrm{Xi}$ 奚, $\mathrm{Xi}$ 霄, and Bohai 渤海 would be honored with titles as kings and given ceremonial instruments, flags and drums, chariots and clothes, weapons and armor, and given emoluments with an honorable send off, to win their full loyalty and perpetual obedience to the emperor's rule.... The nations of $\mathrm{Xi}$, $\mathrm{Xi}$, and Bohai would serve as vassals to keep the four barbarian groups in the outlying border areas in check. ${ }^{10}$

The Song dynasty wanted to establish a protocol in the realm in which the four barbarian groups would be held in check.

After the Song dynasty suffering defeat in the Yongxi campaign, its concept of national security underwent a subsequent change. After the treaty of Chanyuan 澶淵之盟 [1005], the Song dynasty gradually formed a national security based on the "garrisoning administrative districts and defending them" concept mentioned earlier. The Song and the Liao [907-1125] first demarcated clear borders, to acknowledge the actual borders between them, and agreed to "station troops along the border between them in their respective administrative districts, to secure the border area."11 During the reign of the Shenzong emperor 神宗 [r. 1067-1085], the border with Cochin [Jiaozhi 交趾] (an area comprising present-day Vietnam and Guangdong) was also demarcated. The Song emperors Shenzong and Zhezong 哲宗 [r. 1086-1100] established clear borders between the Song and the Western Xia [1038-1227], changing the former practice of demarcating the border based on natural geographic boundaries or ethnic geographical distribution, to the more abstract and political borders on a map. After the Peace Treaty of Shaoxing 紹興和議 [1141], the Southern Song

\footnotetext{
10 Li Tao 李壽, Xu zizhi tongjian changbian 續資治通鑒長編 [Sequel to A Comprehensive Mirror to Aid in Government] (Beijing: Zhonghua shuju, 2004), 27.604.

11 Li Tao, Xu zizhi tongjian changbian, 58.1299.
} 
[1127-1279] and the Jin dynasty [1115-1234] marked the border between them at the Huai 淮 River, "demarcating the border running from Xuyi 盯眙 to Tangdeng 唐鄧,” with “Dasanguan 大散關 as the pass."12 The Southern Song once issued an order to station troops along the Huai River to demarcate the border to be defended. ${ }^{13}$ Under the national security policy based on unifying relations between China and the barbarian groups, the greatest guarantee of national security was the voluntary submission of the four barbarian groups to Chinese authority. The Song dynasty's repeated demarcation of borders between the Song and the "barbarians" demonstrated the change that had occurred in the concept of national defense.

After the Yongxi campaign, the Song dynasty promoted a passive national defense strategy of preventing war by peaceful means, which became a strategy followed by succeeding generations in the Song dynasty.14 The Song dynasty signed a series of peace treaties with the Liao, Xia, and Jin, the powers along the Song's borders. These peace treaties were based on exchanging economic benefits for national security. From the Song perspective, in the context of promoting a passive national security policy based on preventing war by peaceful means, the price of providing economic benefits to others in exchange for a negotiated peace became the best alternative for achieving security and for maintaining "dynastic status" [mingfen 名分]. Accordingly, people in the Song took a positive stance toward establishing peace treaties to maintain national security. The Song dynasty scholar Fan Yu 範育 [d. 1095] said, "Using military means to defend the borders is not as effective as establishing treaties, and establishing treaties is not as effective as upholding good faith." ${ }^{15} \mathrm{Fu} \mathrm{Bi}$ 富弶 [1004-1083] also said that the annual tribute paid by the Song to the Liao dynasty "was less than two percent of the national military budget. From this it can be concluded that the treaty of Chanyuan was not a strategic error."16 $\mathrm{Li}$ Gang 李綱 [1083-1140] assessed the treaty of Chanyuan as an excellent policy,

12 Toqto'a 脫脫, ed., “Wanyan kuang zhuan 完顏匡傳 [Biography of Wanyan Kuang]," in Jinshi 金史 [History of the Jin Dynasty] (Beijing: Zhonghua shuju, 1975), 2169-70; idem, Gaozong 高宗 [Emperor of Gao], in Songshi 宋史 [History of the Song Dynasty] (Beijing: Zhonghua shuju, 1977), 30.556.

13 Li Xinchuan 李心傳, Jianyan yilai xinian yaolu 建炎以來系年要錄 [Record of Important Events since the Jianyan Reign] (Beijing: Zhonghua shuju, 2013), 185.3579; Wu Yong 吴泳, “Bianbei zhazi 邊備答手子 [Random Notes on Border Defenses],” in Helin ji 鹤 林集, Wenyuange siku quanshu yingyinben, $c e$ 1176, 20.195 .

14 Chen Feng 陳峰, “Songdai zhuliu yishi zhipeixia de zhanzheng guan 宋代主流意識支 配下的戰爭觀 [The Concept of War in the Mainstream Thought of the Song Dynasty]," Lishi yanjiu 歷史研究, no. 2 (2009).

15 Li Tao, Xu zizhi tongjian changbian, 228.5548.

16 Fu Bi 富顼, “Shang renzong hebei shouyu shisan ce 上仁宗河北守御十三策 [Presenting Thirteen Strategies to the Renzong Emperor for the Defense of Hebei]," in 
a historical precedent for controlling the barbarian tribes in the north and west. ${ }^{17}$ Following the treaty of Chanyuan, entering into economic treaties in exchange for peace became the standard strategy followed by succeeding generations in the Song dynasty.

It is evident that the principles of "defending against foreign threats can be achieved only after establishing domestic security" and "guarding against potential threats to domestic security while relaxing vigilance against outside threats" defined the fundamental national policy followed by the Song in handling complex domestic and external factors that affected national security. If the Song dynasty had not placed importance on border defenses and strengthening safeguarding of the frontier, it would not have been possible to maintain national security.

Both the Northern and Southern Song placed great importance on military preparations in border defenses. The Song dynasty's overall concept of national security was still based on an organic unity encompassing Chinese-barbarian relations and on a concept of national security based on maintaining domestic security while guarding against outside threats. With the passage of time, this became more passive and more conservative, with the appearance of a passive national defense policy that involved demarcating borders with the Yi 夷 and Di 狄 barbarian groups and maintaining domestic security within these borders.

\section{The Tributary System and Domestic Security}

2.1 The Tributary System and Domestic Political Security

In China's ancient political system, political legitimacy was the primary problem that required resolution. Confucius referred to this when he said, "If one's use of language is not correct, what one says will not be rational; if what one says is not rational, then nothing can be achieved."18 The stability of the Song dynasty first required that the issue of political legitimacy be resolved, that is, the issue of correctness and unity [zhengtong 正統]. In his Discussion of Legitimacy, Ouyang Xiu 歐陽修 [1007-1072] said, “A person who is correct [正者] rectifies all in the realm that is not correct. A person who practices unity

Songchao zhuchen zouyi 宋朝諸臣奏議 [Memorials of Various Song Dynasty Officials to the Emperor], ed. Zhao Ruyu 趙汝愚 (Shanghai: Shanghai guji chubanshe, 1999), 135. 1501.

17 Li Gang 李綱, “Lun shouyu zhazi 論守御札子 [Random Notes on a Discussion of Defenses]," in Li Gang quanji 李綱全集 [Complete Works of Li Gang] (Changsha: Yuelu shushe, 2014), 46. 535 .

18 Huang Kan, Lunyu yishu, 326. 
[統者] unites all things in the realm that are different."19 Correctness and unity refer to the space including the realm of Chinese-barbarian relations: the first is "correctness," which means continuing the path of virtue and legitimacy; the second is "unity" or the unity of Chinese-barbarian relations. One Song dynasty exegete, commenting on the Confucian classic Book of Rites, stated,

The ruler of the realm is called the son of heaven. The realm includes the four frontiers on all sides, and also refers to the four barbarian groups along the borders. In ancient times, people in the central plains called the ruler the heaven-appointed king, while the nationalities along the border called the ruler the son of heaven. ${ }^{20}$

The son of heaven must rule over Chinese and barbarian alike. The establishment of a tributary system with China at the center and the barbarians on the periphery would consolidate the legitimacy of the Song rulers, showing them to be both the de jure and de facto leaders of the empire. This recognition of their legitimacy would be a great boon to national security.

However, the Song dynasty's position of legitimacy did not come easily. It required considerable construction and demonstrative proof. The Song dynasty not only was incapable of uniting the "realm" but often was subject to humiliation by the Yi and Di barbarians. On the one hand, establishing legitimacy entailed defining the path of virtue, setting the beginning of the new year, and implementing the imperial system. On the other hand, it entailed creating a unitary tributary system of Chinese-barbarian relations, to demonstrate that the emperor was the son of heaven. The Song emperors' imperial decrees all contained language referring to the symbiotic relationship between the Chinese at the center and the barbarians on the periphery. An example of this is a decree of the Taizong emperor, which reads, "Whether they are Chinese people of the central plains or nationalities of the border areas, they all pay obeisance," ${ }^{21}$ proclaiming that all people, Chinese and barbarian alike, acknowledged the authority of the emperor.

The ceremony for the worship of heaven and earth held on Mount Tai, and the worship of heaven at the altar built in the southern suburbs of the capital reflected the importance of establishing a tributary system for the sake

19 Ouyang Xiu 歐陽修, “Zhengtong lun 正統論 [Discussion of Legitimacy],” in Jushi ji 居士集 [Collected Works of a Lay Buddhist], in Ouyang xiu quanji 歐陽修全集 [Complete Works of Ouyang Xiu] (Beijing: Zhonghua shuju, 2001), ce 1, 16.267.

20 Wei Shi 衛湜, Liji jishuo 禮記集說 [Collected Commentaries on the Book of Rites], Wenyuange sikuquanshu yingyinben, $c e$ 117, 11.232.

21 Toqto'a, “Gaoli zhuan 高麗傳 [The Chronicle of Gaoli],” in Songshi, 487.14038. 
of domestic political security. The Zhenzong emperor of the Song had been humiliated by the treaty of Chanyuan and the treaty that the Song had been forced to sign with the Yi and Di barbarians. He followed the advice of Wang Qinruo 王欽若 [962-1025], Dingwei 丁謂 [966-1037], and others who believed that it was necessary to cover up these humiliating treaties. Subsequently, grand ceremonies for worshipping heaven and earth were planned, creating a tributary system in which the four barbarian tribes paid allegiance to the Song emperor, thus greatly strengthening the Song's sense of political security. The prime minister Wang Dan 王旦 [957-1017] led a group of over twenty thousand people, which included members of barbarian tribes, and Buddhist and Daoist personages, to petition the emperor five times to request that the ceremony to worship heaven and earth be held at Mount Tai. The ceremony at Mount Tai included tributary ambassadors from the Seljuks [Dashi 大食], Champa [Zhancheng 占城], and other nationalities, assembled at the foot of the mountain. The great ceremony held in the southern suburbs of the capital included tributes offered by the Yi and Di and the conferment of titles by the emperor. This was an exhibition of the tributary system performed solely for the officials and people in China, to maintain an appearance of political legitimacy and domestic security. Accordingly, the construction of the tributary system was a necessary condition for demonstrating the position of the emperor of the Song dynasty as the son of heaven for both the Chinese and the barbarians. In the context of the term "the realm," the son of heaven for the Chinese and the barbarians and his political legality in his domestic role as the emperor of the country embodied a relationship with two faces: ensuring internal safety and securing external relationships.

\subsection{The Disintegration of the Northern Song's Tributary System and the Ensuing Domestic Security Crisis}

The stability of the tributary system had a direct effect on the domestic security of the Song dynasty. Chen Yinque 陳寅恪 [189o-1969] once discussed the interconnection of the rise and fall of tribes outside China during the Tang dynasty and the relationship between external threats and domestic government: "The ascension and decline of China [in the Tang dynasty] and the various tribes outside China with which it had contact was often interconnected with numerous tribes and was not solely related to China's relationship with one single tribe." 22 He also wrote that the Tibetan Kingdom [Tubo 吐蕃] and the decline of the Tang dynasty caused a loss of control in Nanzhao 南詔, which not only

22 Chen Yinque 陳寅恪, Tangdai zhengzhi shi shulungao 唐代政治史述論稿 [A Narrative of the Political History of the Tang Dynasty] (Shanghai: Shanghai guji chubanshe, 1997), 125 . 
became a threat on the Tang border but also contributed to the fall of the Tang dynasty. ${ }^{23}$ The interaction and interconnection between the Song dynasty and various tribes in East Asia follow a pattern very close to the one he describes in his theory. Domestic security was closely related to changes in the external, international environment. Usually, when tributary relations were relatively stable, the Song dynasty had fewer threats to domestic security, and when the tributary system disintegrated, the threats to domestic security increased. In the early years of his reign, the Taizong emperor of the Song dynasty fought with the Liao dynasty to recover the Youyun 幽雲 region and to achieve supremacy among the various tribes in East Asia. The Song dynasty actively formed alliances with political entities and nationalities such as the Korean Kingdom [Gaoli 高麗], Bohai, and Gaochang 高昌. At the same time, these political entities and nationalities sided with the Song and maintained tributary relations with the Song before its approaching decisive battle with the Liao. This type of tributary relationship created an international environment and security guarantees that were extremely advantageous to the Song dynasty.

After the treaty of Chanyuan, the East Asian region in general enjoyed a relatively stable international order. The tributary system for the Song and Liao dynasties continued to exist, although some political entities and nationalities, such as Gaoli and the Jurchens [Nüzhen 女真], broke away from the Song dynasty's tributary system. Nonetheless, the Song dynasty's tributary system internally maintained relatively stable relations. Among the various countries directly related to its national security, the Song formed an alliance in the northwest with the Tibetans to control the Western Xia and in the south united with the Champa to control Jiaozhi. At the same time, the Song used economic means to maintain stable relations with the Liao and Xia, which had satisfactory results. Despite minor local crises, they did not constitute serious threats to domestic security.

Beginning when the Shenzong emperor of the Song forcefully expanded the borders, the relatively stable international order was gradually shaken and disintegrated, to the point that it became an important factor in the downfall of the northern Song. On the one hand, the Song dynasty's forceful expansion of the borders led to changes in international conditions in East Asia. The Shenzong emperor of the Song dynasty activated a plan to forcefully expand the borders, which involved first taking back Hehuang 河湟, then annihilating the Western Xia, and finally seizing Youyan 幽燕, with the ultimate objective of swallowing up the Liao dynasty. On the southern border, the plan to “recover" Jiaozhi was reactivated, which resulted in the Xining war 熙寧戰爭 
[1075-1076] between the Song dynasty and Jiaozhi. The Shenzong emperor's attempt to forcefully expand the borders resulted in a disastrous defeat for the Song on all sides, which greatly diminished the Song dynasty's international status and international influence, as the rather orderly tributary system underwent a breakup that resulted in hostile relations. From this time on, the power of the Western Xia and Liao dynasties infiltrated the Tubo of the Hehuang region, to the point that the Tubo joined forces with the Western Xia and the Liao to oppose the Song dynasty.

During the late years of his reign, the Shenzong emperor of the Song dynasty adopted a policy of retrenchment and during the Yuanyou 元祐 [1086-1094] reign, he adopted a relatively conservative policy. However, during the years of the “Shaosheng Shaoshu” 紹聖紹述 [1094-1097] reign, forceful expansion of the borders was reinitiated. Especially during the reign of the Huizong emperor of the Song 宋徽宗 [1100-1126], large-scale forceful expansion of the borders continued. From the second year of the Chongning 崇寧 [1102-1106] reign to the first year of the Xuanhe 宣和 [1119-1125] reign under the Huizong emperor of the Song, activities to forcefully expand the border were discontinued, after having wrested Qingtang 青唐 from the Tubo and a large area that had been under the jurisdiction of the Western Xia. The huge success of the campaign to forcefully expand borders in the northwest spurred the ambitions of the Huizong emperor and his officials to pursue even greater achievements. As stated by Chen Bangzhan 陳邦瞻 [1557-1628] of the Ming dynasty [1368-1644], "Having achieved victory over the Western Xia, they believed that they could also conspire against the Liao." ${ }^{24}$ They began to scheme to recover Youyan and actively provoked the Liao dynasty. They sent an emissary to the Liao dynasty to gather information, made preparations for war, and accepted the proposal of Ma Zhi 馬植 [d. 1126] of the Liao dynasty to "ally with the Jurchens and jointly attack the Liao."25 They proactively sent an emissary to contact the Jurchens to create an "overseas alliance," which became a necessary component of the military campaign against the Liao.

On the other hand, at the beginning of the twelfth century, the Jurchens, who had been vassals of the Liao dynasty, rose up, established their own state, and raised an army to fight against the Liao. International political conditions in East Asia were pregnant with tremendous change. The Huizong emperor

24 Chen Bangzhan 陳邦瞻, “Fu Yanyun 复燕云 [Reacquisition of the Yanyun Area]," in Songshi jishi benmo 宋史紀事本末 [A Chronological History of the Song Dynasty] (Beijing: Zhonghua shuju, 2015), 539 .

25 Xu Mengshen 徐夢莘, “Zhengxuan Shangzhi 政宣上帙," in Sanchao beimeng huibian 三朝北盟會編 [A Chronicle of War and Peace with the Liao under Three Emperors of the Song Dynasty] (Shanghai: Shanghai guji chubanshe, 1987), 1.1. 
and his officials believed that this opportunity aligned with their plan to forcibly expand the borders and accordingly actively took action. Gaoli advised the Song dynasty: "The Liao was a like a brother to the Song, and its existence served to safeguard the border against invasion by other tribes. The Jurchen are wolves and tigers with whom you cannot make friends." ${ }^{26}$ Gaoli spoke in the interest of the safety of the Song dynasty, in the hope that it would maintain relations with the Liao and the stability of the international order in East Asia. The Liao also hoped that the Song would not ally with the Jurchens to attack it. "In the interest of momentary gain, the Song is giving up a century of amicable alliances, to take jackals and wolves as neighbors, planting the seeds of future disaster."27 Various individuals in the Song dynasty also voiced their opposition: "The Song will destroy a weak, small enemy to become neighbors with a strong one"; "The day will certainly come when the Jurchens will take the initiative to break their treaty with the Song and become a serious threat to China." ${ }^{28}$ However, these rational opinions were disregarded by the Huizong emperor in his obsession to expand the borders and determination to unite with the Jin to destroy the Liao.

The rise of the Jurchens not only caused the internal disintegration of the tributary system for the Liao but also destroyed the overall international order in East Asia created by the balance and stability of the tributary system between the Song and Liao dynasties, which ultimately led to the destruction of the Song by the Jin. If the northern Song had consistently maintained peace between the Song and the Liao and a balanced state of affairs under the dynasty's tributary system, it could have dealt with the change in the situation caused by the Jurchens' opposition to the Liao; otherwise, it would not have been able to prevent the Jin dynasty from destroying the Liao dynasty and would definitely have been able to prolong its own existence. It might be said that the Northern Song's ambition to forcefully expand its borders continued to grow. Its destruction of the dynasty's tributary system and the stability of Song and Liao relations and its misjudgment and mishandling of the change of circumstances in East Asia were important factors in hastening the destruction of the dynasty.

The destruction of the Northern Song's political power was only the first stage of the domestic security crisis faced by the Song dynasty ruled by the

26 Toqto'a, "Gaoli zhuan," 487.14049.

27 Toqto'a, “Chong Shidao zhuan 種師道傳 [Biography of Chong Shidao]," in Songshi, 335.1075o.

28 Song Zhao 宋昭, “Shang huizong lun nüzhen juexianbai meng 上徽宗論女真決先敗 盟 [Memorial to Emperor Huizong on the Certainty of the Jurchens' First Breaking Their Treaty with the Song in the Future]," in Songchao zhuchen zouyi, 142.16o3. 
Zhao family. The collapse of the Northern Song dynasty was first followed by the loss of order in the areas ruled by the Southern Song. Mass uprisings broke out throughout the country, such as the uprising in Hubei led by Yang Yao 楊麼 [1108-1135], the uprising in Hunan led by Deng Zhuang 鄧裝, the uprising in Fujian led by Fan Ruwei 範汝為 [d. 1132], and Ju Zheng 居正 in Zhejiang. Officials such as Zhang Bangchang 張邦昌 [1081-1127], Liu Yu 劉豫 [1073-1146], Miao Fu 苗傅 [d. 1129], and Liu Zhengyan 劉正彥 [d. 1129], who had formerly served the dynasty, turned against it. The dynasty's routed troops ran amok everywhere, such as those under Li Cheng 李成 [d. 1158], Kong Yanzhou 孔彥舟 [1106-116o], and Cao Cheng 曹成 [b. 1113]. Zhu Shengfei 朱勝非 [1082-1144] stated: "Today, there are primarily three causes of armed disruption: the Jin, local thieves and wandering bandits." ${ }^{29}$ When disloyal officials are added to the equation, domestic order was basically out of control. In addition, the people were in a state of confusion. The collapse and breakdown of order in Yangzhou 揚州 marked the beginning of people's loss of confidence in the Southern Song. When the Gaozong emperor 高宗 [r. 1127-1162] of the Song received news of the Jin's defeat of the Song army at Tianchang 天長, he fled in the company of only five or six mounted escorts. When the government officials and the people witnessed this, they fled south in a panic. In the confusion of the flight for their lives, relations between ruler and officials disintegrated, to the point that the Gaozong emperor stabbed to death one of his bodyguards, who he believed had been impertinent. When the Gaozong emperor and his officials reached Yuezhou 越州, he decreed that the officials accompanying him could remain or leave as they pleased. The Gaozong emperor also said, "Literati and officials should be aware of their duties and principles, how can they be disobedient? If they behave as such [as they did in the past], I the emperor am nothing more than a bandit or insurgent." In fact, many officials abandoned the Gaozong emperor. ${ }^{30}$ When fleeing Hangzhou 杭州, the Longyou empress 隆祐 太后 [1073-1131] and her entourage scattered on the way to Jiangxi. When they reached Taihe 太和 county, the 10,00o troops in her entourage dispersed, with less than 100 remaining, while the officials accompanying her fled to the mountains and valleys, and the items she had brought with her were almost completely stolen. When she reached Qianzhou 虔州, a dispute erupted between the local militia and her guards, and her life was threatened. The rebellious local militia refused to follow her orders, and the officials and soldiers who had accompanied her, when faced with this problem, refused to intervene. Given the diminished authority of the emperor at that time, if the Gaozong

29 Li Xinchuan, Jianyan yilai xinian yaolu, 42.905.

30 Li Xinchuan, Jianyan yilai xinian yaolu, 29.677. 
emperor or the Longyou empress had given an order threatening Jin troops or the dynasty's rebellious troops, the Song dynasty under the Zhao family would have completely lost any possibility of reconstruction. The destruction of the existing international order seriously threatened not only the national security of the Southern Song dynasty but also the lives of the Gaozhong emperor and Longyou empress, which were hanging by a thread. The general population suffered an even crueler fate. After Yangzhou capitulated, over a hundred thousand people died, mostly from falling into the river and drowning. The Jin pillaged and slaughtered wherever they went, and the entire population of places such as Hongzhou 洪州 and Dingzhou 鼎州 was butchered.

After the Jin overran Kaifeng 開封 and took the two Song emperors hostage, any effective guarantee of the Song dynasty's national security was lost. The ruler and his officials showed no concern for one another, and the people and their ruler gave one another no protection. The Gaozong emperor of the Song dynasty was like a small boat buffeted by high swells, the Jin were like a fierce wind, and the disorder was like a huge wave. Any sense of security had disappeared. The Jin dynasty refused to recognize the political authority of the Southern Song, which meant that the parties were at war with each other. Given the overwhelming military power of the Jin, the precondition for the Gaozhong emperor to reestablish domestic order and national security was whether stable relations could be built with the Jin and whether the Southern Song could obtain diplomatic recognition from the Jin dynasty and reconstruct a new international protocol. The Gaozong emperor of the Song pleaded with the Jin, saying, "He was willing to do away with the existing title of the dynasty and recognize all the realm as the sovereign territory of the great Jin, with the Liao having supreme authority."31 It was his wish that the reestablished international protocol be a unified tributary system under the Jin. Under the peace treaty of the eighth year of the Shaoxing 紹興 [1131-1162] reign, the Song dynasty acknowledged that it was a vassal of the Jin dynasty, under an official ruler-vassal relationship, and was officially admitted to the Jin dynasty's tributary system. When the troops and the people of the Southern Song witnessed the Gaozong emperor, the son of heaven of the great Song dynasty, paying obeisance to the barbarian Jin dynasty as its subordinate vassal, they were moved to tears. The Gaozong emperor said, "with words and an expression which conveyed conviction," "Literati and officials think only of themselves; in the past at Mingzhou 明州, I did not hold them responsible for their actions." ${ }^{2}$ This expresses the Gaozong emperor's feelings when his officials deserted him

31 Li Xinchuan, Jianyan yilai xinian yaolu, 26.524.

32 Li Xinchuan, Jianyan yilai xinian yaolu, 124.2024. 
and the people were disloyal to him as he was being pursued by the Jin, an expression of his fear and hatred acting as a vassal to the Jin in exchange for security that could not be obtained [otherwise].

Under the peace treaty of Longxing 隆興和議 [1164], the relationship between the Song and the Jin changed. However, it was not until the eighth year of the Jiading 嘉定 [1208-1224] reign that the Song discontinued giving annual monetary tribute payments to the Jin dynasty. The situation in East Asia in general was an international order under the leadership of the Jin dynasty. The Southern Song's tributary system had shrunken considerably in comparison to the Northern Song, with the dynasty taking an even more passive stance. The various countries in the northwest, Gaoli, and Dali 大理 gradually disengaged completely from the tributary system of the Southern Song. The only countries that had tributary dealings with the Southern Song were Jiaozhi, Champa, Srivijaya [Sanfoqi 三佛齊], Seljuks, the Khmer [Zhenla 真臘], Zhenlifu 真裡富, and the Lopbun [Luohu 羅斛] kingdom. With the exception of Jiaozhi, which maintained relatively stable relations with the Southern Song under which tribute was paid and titles were conferred, the other country that paid the most tribute was Champa, which made six tribute payments, primarily in connection with trade. ${ }^{33}$ Although it was necessary to construct a tributary system under the dynasty to give domestic credibility to the political legality of the Southern Song, the role of the tributary system as a factor in domestic political security cannot be overlooked. However, given that the Jin dynasty dominated the international order and in light of the actual power possessed by the Southern Song, there was neither the possibility nor the hope that the dynasty could restore the tributary system under the Northern Song.

As stated above, the concept of national security in ancient China, including the Song dynasty's concept of national security, included China and the barbarians. The Song dynasty, especially the Northern Song, placed great importance on constructing overall security under a China-barbarian protocol. Liu Anshi 劉安世 [1048-1125], in opposition to the Song dynasty's construction of the capital, said,

33 Huang Chunyan 黃純霊, “Nansong chaogong tixi de goucheng 南宋朝貢體系的構成 [The Construction of the Southern Song's Tributary System]," in Songdai chaogong tixi yanjiu 宋代朝貢體系研究 [Research on the Song Dynasty's Tributary System] (Beijing: Shangwu yinshuguan, 2014), 125-40. 
The son of heaven has a duty to defend the country against the four barbarian tribes. If the emperor's capital city becomes a tool for defending against the incursions of the enemy, what is the use of outside defenses? ${ }^{34}$

Fan Zuyu 范祖禹 [1041-1098] also said, "The son of heaven must guard against the four barbarian tribes.... Why is there a need to build a capital city?"35 On the one hand, they were opposed to expending labor and squandering funds on building a capital city. On the other hand, they emphasized that constructing a tributary system under which the four barbarian tribes yielded to Chinese authority was the basic safeguard of national security. This holistic concept of security included China and the barbarians (the parties paying tribute). The Song dynasty constructed the tributary system to establish an international order that was advantageous to the country's security; at the same time, the stability of the international order was advantageous to the security of the various countries in the tributary system. It can be said that the tributary system was a system for international security and that the countries in the tributary system constituted a security community.

The Song dynasty primarily constructed the tributary system to safeguard national security. The Song established a tributary system centered on the dynasty. This system constituted the international order that it led. The stability of the tributary system anchored the security and stability of the Song dynasty's international environment. The Song dynasty maintained the tributary system by military and economic means, to strengthen the dynasty's security. In its tributary relations with the Western Xia, the Song dynasty used the Western Xia to hold the Liao dynasty in check and reduce the threat from the Liao dynasty. When the Liao dynasty attacked the Western Xia, the Song took a stance of non-intervention while maintaining relations with the Western Xia under which tribute was paid and titles were bestowed, to maintain its peace treaty with the Western Xia, so that the Khitans would not dare to lightly sever what were seen as peaceful and friendly relations between the two countries and create a threat. "Enable Yuanhao 元昊 [1003-1048] [the ruler of the Western Xia] to concentrate his strength to advance eastward with his army, to fight for supremacy against the Khitans. If the two countries are continuously

34 Liu Anshi 劉安世, “Qi baxiu jingcheng 乞罷修京城 [Request to Discontinue Construction of the Capital]," in Jinyan ji 盡言集, in Wenyuange sikuquanshu yingyinben, $c e$ 427, 6.241.

35 Fan Zuyu 范祖禹, “Shang Zhezong qi baxiu jingcheng 上哲宗乞罷修京城 [Memorial to the Zhezong Emperor Requesting that the Construction of the Capital Be Discontinued]," in Songchao zhuchen zouyi, 126.1393 . 
at war with one another, this is most advantageous to the Song." ${ }^{36}$ At the same time, the border trade and exchange of tribute and valuables formed the backdrop of the tributary relationship and bestowing of titles between the Song and the Xia. If the Western Xia destroyed the tributary system, the Song would "discontinue annual emoluments and prohibit trade between the two countries." ${ }^{37}$ In this way, the Song used economic means to maintain tributary relations between the two countries. The Song dynasty also maintained tributary relations with the Tibetans, causing them to hold the Western Xia in check and reduce threats to national security originating with the Western Xia. The reason that the Western Xia "ultimately did not dare to deeply penetrate the Guanzhong 關中 region was the presence of Gusiluo 唃廝囉 and other tribes, which would not acquiesce to the Western Xia and thus were a source of concern on their rear flank." 38

Various countries that maintained tributary relations with the Song enjoyed economic benefits gained in the "favorable imbalance of trade" in their tributary exchanges and commercial trade with the Song, and, at the same time, these relations were also advantageous to the Song dynasty's national security. If the Song dynasty were to "discontinue annual emoluments and prohibit trade between the Song and the Western Xia," this would cause the Western Xia to suffer "a domestic shortage of clothing and food, reduce people to poverty and hunger, and threaten their survival." 39 In response to the tribute given by the Song dynasty, the Western Xia could "proclaim themselves vassals of the Song in name only, while actually doing so to obtain over 250,000 in emoluments." ${ }^{40}$ When the profits from the trade with the Song were added to this, the huge economic benefit obtained from the Song not only enhanced the power of the Western Xia but also diminished any threat from the Song dynasty. At the same time, this served to alleviate its concern over defending itself against the Liao. The Western Xia also maintained a tributary relationship with the Liao dynasty and used it to hold the Song dynasty in check. This formed a double-pronged strategy with the head and the tail corresponding

36 Yang Shiqi 楊士奇 et al., ed., “Yubian 禦邊” and “Siyi 四裔," in Lidai mingchen zouyi 歷代 名臣奏議 [Memorials of Famous Officials Throughout Various Dynasties], in Wenyuange sikuquanshu yingyinben, ce 442, 326.16o, 342.557.

37 Li Tao, Xu zizhi tongjian changbian, 479.11412.

38 Toqto'a, "Sun Fu zhuan 孫甫傳 [Biography of Sun Fu]," in Songshi, 295.9840.

39 Li Tao, Xu zizhi tongjian changbian, 405.9863.

40 Han Qi, “Shang renzong lun xibei yihe you dayouzhe san dalizhe yi 上仁宗論西北議和 有大憂者三大利者一 [Memorial to the Ren Zong Emperor on Three Great Concerns and One Great Benefit of Making Peace in the Northwest]," in Songchao zhuchen zouyi, 136.1516 . 
with each other. ${ }^{41}$ The Liao dynasty dispatched troops to threaten the Song on many occasions when the Song fought with the Xia and thus helped the Western Xia to recover territory. The Liao as a third party also reaped benefits from the conflict between the two.

Gaoli, as a small country wedged between two large dynasties, the Song and the Liao, regarded its own national security as its highest goal, in handling relations with the Song and the Liao. In the words of its ruler and ministers when discussing policy toward the Song and the Liao, "Our country's establishment of good relations with the Liao ensures that war will not break out on the border and that our people can lead happy lives. Safeguarding our country in this way is the best policy" 42 At the beginning of the Northern Song, Gaoli acknowledged the Song dynasty's imperial authority. Before the Yongxi campaign, the Taizong emperor of the Song ordered Gaoli to dispatch troops to surround and attack the Liao dynasty. Gaoli and the other tribes in the Northeast, hoping that the Song dynasty would achieve victory, sided with the Song, in the expectation that their security would be assured in the aftermath of a decisive Song victory over the Liao. After the Yongxi campaign, when Gaoli suffered a military invasion by the Liao, it received no protection from the Song dynasty. "Having given tribute to the Song dynasty year after year, the dynasty refuses to protect us. Therefore, we have decided to become vassals of the Khitans." ${ }^{\text {"4 }}$ Gaoli gradually came under the sway of the Liao dynasty.

During the early years of the Northern Song, Champa's tributary relationship with the Song dynasty also became an important factor in the dynasty's national security. In its early years, the Northern Song harbored the objective of "recovering" Jiaozhi and allied with Champa to keep Jiaozhi in check. In its tributary relationship with Champa, the Northern Song on many occasions gave Champa warhorses, bows, swords, and other military implements, which it did not give to other countries, in the interest of mitigating and controlling Jiaozhi's invasion and harassment of Champa. These types of special treatment elevated Champa's status among the various countries along the border. The king of Champa said,

In the past, when we paid tribute, we did not receive gifts of flags, bows and arrows. Today it is my great honor to be the sole recipient of such special gifts.... When neighboring countries heard this news, and learned that I enjoyed a special favored status bestowed by a great country, all of

41 Li Tao, Xu zizhi tongjian changbian, 124.2927.

42 Sun Xiao 孫曉, ed., “Wenzong shijia 文宗世家," in Gaoli shi 高麗史 [History of Gaoli] (Chongqing: Xi'nan shifan daxue chubanshe, 2014), 8.218.

$43 \mathrm{Fu} \mathrm{Bi}$, "Shang renzong hebei shouyu shisan ce," 1507. 
them were in fear of the heavenly authority (of the Song) and dared not conspire to harm me. ${ }^{44}$

In the first year of the Chunhua 淳化 [990-994] reign, Champa complained to the Song dynasty that Jiaozhi had invaded Champa, and the Song dynasty told Jiaozhi that "each country should safeguard its respective territory" 45 The Song dynasty's prestige as a large country and Jiaozhi's economic demands submitted to the Song dynasty enabled the Song dynasty to a certain degree to restrain Jiaozhi's invasion and harassment of Champa. After the Xining campaign, the Song dynasty abandoned its objective of "recovering" Jiaozhi as well as its favorable treatment and protection of Champa. Champa gradually fell completely under Jiaozhi's control.

Naturally, the tributary system was not a panacea that provided a comprehensive solution to national security. In their tributary relations with the Song dynasty, under normal conditions certain political entities could remain within their borders, while others maintained their tributary relations with the Song while, at the same time, invading, harassing, and swallowing up the Song dynasty's territory. The Song dynasty's relations with Jiaozhi followed this pattern. The people of the Song said, "Although Jiaozhi pays tribute, it actually harbors ill will toward the dynasty and often swallows up our territory." 46 During the Tiansheng 天聖 [1023-1031] reign of the Northern Song, the Song dynasty's border with Jiaozhi was at Yunhedong 雲河洞. By the fourth year of the Jiaoyou 嘉祐 [1056-1063] reign, Yunhedong was located "several hundred li inside barbarian territory." ${ }^{47}$ With respect to Gaoli, Champa, and other countries that to a great extent came under the influence of the international order constructed by the tributary system, the tributary system also became just one factor that safeguarded their respective country's national security.

\section{Conclusion}

The ancient tributary system did not serve merely to satisfy the vanity of a large country. As a type of international protocol, it was also an important factor in maintaining national security, as a holistic and complex national security mechanism. The Song dynasty's concept of national security was identical to that of other imperial dynasties in ancient China. It was a holistic security

\footnotetext{
44 Toqto’a, “Zhancheng zhuan 占城傳 [Chronicle of Champa]," in Songshi, 489.14081.

45 Toqto'a, "Zhancheng zhuan," 14080.

46 Toqto'a, "Xiao Zhu zhuan 蕭注傳 [Biography of Xiao Zhu]," in Songshi, 334.10733.

47 Li Tao, Xu zizhi tongjian changbian, 190.4593.
} 
concept based on Chinese-barbarian relations, which regarded "defending against the four barbarian groups" as the most ideal security model. The basis of this concept of security held by countries under this model included maintaining domestic security while, at the same time, securing borders and guarding against external threats. Establishing a tributary system that included Chinese and barbarians not only was significant in terms of political security by providing a justification for legitimate political authority but also had multiple practical security applications. The stability and destruction of the tributary system was closely connected to the national security of the Song dynasty. During the early years of the Northern Song, the tributary system was relatively stable and played a dynamic role in the Song dynasty's national security. In the later years of the Northern Song dynasty, because of changes in the political situation in East Asia and the Song dynasty's mishandling of these changes, the Northern Song's tributary system and the existing international protocol in East Asia disintegrated, resulting in the destruction of the Northern Song and the serious national security crisis that occurred in the early days of the Southern Song. The Southern Song joined the tributary system reconstructed by the Jin dynasty, which became an important factor to enable the Southern Song to establish its sovereignty. The tributary system was strongly connected to the security of all the participating countries paying tribute and constituted an international security system. The Song dynasty and all the countries in the tributary system shared mutual benefits and also had conflicts of interest. Their relationships involved mutual resistance and rivalry along with mutual cooperation and exploitation in an interconnected and dynamic mode of security.

\section{Translated by George Flournoy}

\section{Works Cited}

Chen Bangzhan 陳邦瞻. “Fu Yanyun 复燕云 [Reacquisition of the Yanyun Area]." In Songshi jishi benmo 宋史紀事本末 [A Chronological History of the Song Dynasty], 539-54. Beijing: Zhonghua shuju, 2015.

Chen Feng 陳峰. “Songdai zhuliu yishi zhipeixia de zhanzheng guan 宋代主流意識 支配下的戰爭觀 [The Concept of War in the Mainstream Thought of the Song Dynasty]." Lishiyanjiu 歷史研究, no. 2 (2009): 38-50.

Chen Yinque 陳寅恪. Tangdai zhengzhi shi shulun gao 唐代政治史述論稿 [A Narrative of the Political History of the Tang Dynasty]. Shanghai: Shanghai guji chubanshe, 1997 . 
Chunqiu zuozhuan zhushu 春秋左傳注疏 [Commentary and Annotation on the Zuo Commentary]. Wenyuange siku quanshu yingyinben 文淵閣四庫全書影印本, ce 144. Beijing: Zhonghua shuju, 199o. [Photocopy of the Wenyuange Edition of the Siku quanshu]

Guo Pu 郭璞. Erya 爾雅. Beijing: Zhonghua shuju.

Huang Chunyan 黃純澧盍. “Nansong chaogong tixi de goucheng 南宋朝貢體系的構成 [The Construction of the Southern Song's Tributary System].” In Songdai chaogong tixi yanjiu 宋代朝貢體系研究 [Research on the Song Dynasty's Tributary System], 125-40. Beijing: Shangwu yinshuguan, 2014.

Huang Kan 皇㑆. Lunyu yishu 論語義疏 [Annotations on the Analects], annot. Gao Shangju 高尚智. Beijing: Zhonghua shuju, 2013.

Ji Xuejuan 紀雪娟. “Beisong 'shounei xuwai’ guoce de zairenshi 北宋 “守内虚外” 国策 的再认识 [Reassessing the Northern Song's National Policy of 'Guarding against Potential Threats to Domestic Security while Relaxing Vigilance against Outside Threats']." Shandong shifan daxue xuebao 山東師範大學學報, no. 5 (2013): 114-21.

Li Gang 李綱. "Lun shouyu zhazi 論守禦答子[Random Notes on a Discussion of Defenses].” In Li Gang quanji 李綱全集 [Complete Works of Li Gang], 46.535. Changsha: Yuelu shushe, 2014.

Li Hequn 李合群. “Beisong 'shounei xuwai' guoce zhiyi 北宋 “守內虛外” 國策質疑 [Queries on the Northern Song's National Policy of 'Guarding against Potential Threats to Domestic Security While Relaxing Vigilance against Outside Threats']." Shixue yuekan 史学月刊, no. 12 (2009): 41-47.

Li Tao 李壽. Xu zizhi tongjian changbian 續資治通鑒長編 [Sequel to A Comprehensive Mirror to Aid in Government] .Beijing: Zhonghua shuju, 2004.

Li Xinchuan 李心傳.Jianyanyilaixinianyaolu 建炎以來系年要錄 [Record of Important Events since the Jianyan Reign]. Beijing: Zhonghua shuju, 2013.

Liu Xu 劉昫, comp. Jiu Tang shu 舊唐書 [Old History of the Tang Dynasty], vol. 62. Beijing: Zhonghua shuju, 1975 .

Ouyang Xiu 歐陽修. “Zhengtong lun 正統論 [Discussion of Legitimacy].” In Jushi ji 居士集 [Collected Works of a Lay Buddhist], 16.218. In Ouyang xiu quanji 歐陽修全集 [Complete Works of Ouyang Xiu], ce 1. Beijing: Zhonghua shuju, 2001.

Sima guang 司馬光, ed. “Tangji 唐紀 [Records of the Tang].” In Zizhi tongjian 資治通 鑒 [A Comprehensive Mirror to Aid in Government], vol. 193, ce 13. Beijing: Zhonghua shuju, 1956.

Sun Xiao 孫曉, ed. “Wenzong shijia 文宗世家”. In Gaoli shi 高麗史 [History of Gaoli], vol. 8. Chongqing: Xi'nan shifan daxue chubanshe, 2014.

Toqto'a 脫脫, ed.Jinshi 金史 [History of the Jin Dynasty]. Beijing: Zhonghua shuju, 1975. Toqto'a 脫脫, ed. Songshi 宋史 [History of the Song Dynasty]. Beijing: Zhonghua shuju, 1977. 
Wang Yunwu 王雲五; Zhu Jingnong 朱經農, ed. Liji 禮記 [Book of Rites]. Shanghai: Shangwu yinshu guan, 1947.

Wei Shi 衛湜. Liji jishuo 禮記集說 [Collected Commentaries on the Book of Rites]. Wenyuange sikuquanshu yingyinben, $c e 117$.

Wu Yong 吳泳. Helin ji 鹤林集. Wenyuange siku quanshu yingyinben, ce 1176.

Xu Mengshen 徐夢莘. “Zhengxuan Shangzhi 政宣上帙.” In Sanchao beimeng huibian 三朝北盟會編 [A Chronicle of War and Peace with the Liao under Three Emperors of the Song Dynasty], 1.1-11. Shanghai: Shanghai guji chubanshe, 1987.

Yang Shiqi 楊士奇 et al., ed. Lidai mingchen zouyi 歷代名臣奏議 [Memorials of Famous Officials Throughout Various Dynasties]. Wenyuange sikuquanshu yingyinben, ce 442.

Zhao Ruyu 趙汝愚, ed. Songchao zhuchen zouyi 宋朝諸臣奏議 [Memorials of Various Song Dynasty Officials to the Emperor]. Shanghai: Shanghai guji chubanshe, 1999. 